\title{
Learning Problem Posing Based on Hot Potatoes Application to Improve Concept Understanding and Problem Solving in Elementary School Mathematics on Flat-Building Materials
}

\author{
Emy Anggraini ${ }^{1 *}$, Siti Maghfirotun Amin ${ }^{2}$, Tatag Yuli Eko Siswono ${ }^{3}$ \\ Primary Education, Postgraduate, Universitas Negeri Surabaya
}

\begin{abstract}
This study aims to improve students' conceptual understanding and problem solving through the application of problem posing learning based on the hot potatoes application based on the problems of the fifth semester students of SDK Maria Fatima Bangkalan. This study uses a quantitative approach. Quantitative research is carried out by describing the data in the form of numbers, namely to determine whether there are any consequences of problem posing learning based on the hot potatoes application on concept understanding and problem solving. The subjects of this study were fifth grade students of Maria Fatima Catholic Elementary School, Bangkalan, Academic Year 2019 - 2020 with flat-building material. The results showed: (1) The effect of problem posing learning based on the hot potatoes application on students' understanding of mathematical concepts was higher with an average value of 85.83 than the control class. (2) The effect of problem posing learning based on hot potatoes application on problem solving has a higher average value than the control class, namely 88.68. (3) The effect of problem posing learning based on hot potatoes application can improve concept understanding and problem solving. Based on the results of data analysis, it can be concluded that problem posing learning based on hot potatoes application can improve the conceptual understanding and problem solving of elementary school students, but still requires adjustment to the situation and conditions at school.
\end{abstract}

Keywodrs:- Problem Posing Learning, Hot Potatoes Application, Concept Understanding, Problem Solving

\section{INTRODUCTIAN}

The development of Human Resources in all aspects of their personality and life is influenced by factors of education, and education has a vital role in human life skills. In addition, education has an impact on one's maturity to achieve a higher level of life or livelihood. Education that not only prepares students for a profession or position, but to solve the problems it faces in everyday life is good education (Trianto, 2008). One of the pillars of education is mathematics. Mathematics as one of the basic sciences, both its applied aspects and its reasoning aspects, has an important role in mastering science and technology.
Therefore, to develop intelligence, skill abilities and to shape students' personalities, the functions of school mathematics subjects need to be applied.

Basic science has an important role in the development of science and technology, is mathematics, because it can develop reasoning power, logical, systematic, and critical thinking. The role of mathematics is not only felt in the field of mathematics but its application is also in other fields. Therefore, all aspects that have a role in education in schools, such as: government, teachers, school principals and related parties have made efforts to improve the quality of education in Indonesia.

Problem solving is part of the mathematics curriculum which is very important because in the learning process and its solution students may gain experience using the knowledge and skills they already have to apply to problem solving. Problem-solving ability is one of the five mathematical competency standards which are the main goals in mathematics learning set by the National Council of Teachers of Mathematics (NCTM) and the Indonesian mathematics education curriculum (Depdiknas). In addition, researchers in the field of education also place problem solving as an important object in their research, including Romberg and Schoenfeld, who state that problem solving is one aspect of ability that is included in the higher order thinking category that must be mastered by students. Problem solving abilities are able to train students to learn to find various approaches to a problem.

One of the competences or mathematical abilities which is the goal of learning mathematics at the elementary and intermediate levels is the ability to solve or solve problems. This is written in the Annex to the Regulation of the Minister of Education and Culture of the Republic of Indonesia Number 21 of 2016 concerning the Standard Content of Primary and Secondary Education which states that one of the competencies for the basic education level (Class VI - IX) in mathematics is so that students have competence " logical, critical, analytical, careful, and thorough, responsible, responsive, and not easy to give up in solving problems. Thus, problems solving or solving perl problems are more often given to students because they are a form of application in everyday life. 
According to Polya (1973) there are four important steps that must be taken in solving math problems, namely (1) understanding the problem; (2) device a plan; (3) carry out the plan; (4) looking back. Meanwhile, according to Krulik and Rudnick (1988), there are five stages in problem solving, namely: (1) reading and thinking (read and think); (2) explore and solve (explore and plane); (3) choose a strategy (select a strategy); (4) looking for an answer (find an answer); (5) reflect and extend (reflect and extend). Problem solving is very important in the learning process of mathematics. Therefore, students must know how to solve math problems, so that students will be directed to develop their abilities in solving math problems. The ability of students to solve problems is considered very important, because in their daily lives students are always faced with real problems that need solutions. Hosnan (2014: 68) states that in order to bring out their understanding and problem solving, students must actively build their knowledge based on their intellectual abilities, one of which is the ability to solve mathematical problems.

Based on the description above, it can be concluded that the Ministry of National Education and NCTM have determined that problem solving is an important process in realizing the objectives of learning mathematics. This statement shows that problem solving is the main process for developing students' thinking in mathematics, so that the problem solving process needs to be nurtured and owned by students in mathematics learning activities. The main asset in problem solving is conceptual understanding, because in determining a problem-solving strategy it is necessary to master the concepts that underlie the problem. Mathematics subjects starting from elementary school to high school level as stated in the 2016 curriculum, illustrate the importance of mathematics education from an early age, because the essence of mathematics is (1) understanding mathematical concepts, explaining the relationship between concepts and applying concepts or algorithms that are flexible, accurate, efficient, and precise in solving problems, (2) using reasoning on patterns and properties, manipulating, compiling evidence, or explaining mathematical ideas and statements, (3) solving problems which include the ability to understand problems, design mathematical model.

NCTM (2000) states that "urge teachers to create an environment where students learn mathematics with understanding" means that NCTM standardizes that in the learning process, teachers must create situations that facilitate students to learn with understanding. Understanding is not only understanding how to do something but also about why it is done. Hiebert and Carpenter (1992) state "With the acquisition of both procedural knowledge and conceptual understanding, students are more to develop skills related to applicability and obtaining an understanding of connected ideas in mathematics" which means that by having procedural and conceptual understanding, students are able to develop skills. related to other mathematical ideas. Therefore,
Indications of low assessment of students' high math scores in terms of five aspects of mathematical abilities according to NCTM (2000), namely the ability to solve mathematical problems, mathematics communication, mathematical reasoning, understanding concepts and mathematical connections. The five indications of low and high assessment of students' math scores are also called math power or math skills. Understanding concepts according to the Ministry of National Education is one of the elements of mathematical skills or skills that are expected to be achieved in learning mathematics, namely by demonstrating an understanding of the mathematical concepts being learned, explaining the relationship between concepts and applying the concepts in a flexible, accurate, efficient and precise manner in solving problems, it is expected that understanding concept and problem solving increases the need for improvement in the learning process. According to Ruseffendi (2006: 328) learning mathematics in schools has been through notification (by means of lectures or expository), reading, imitating, seeing, observing, and so on, not obtained through discovery. So that it has an impact on student errors in understanding mathematical concepts. Example: a student's error is that the student forgets (mistakenly) uses a formula to be used in solving a problem caused by the tendency of students to only memorize the formula, not understand how the formula occurs, so that what they learn is easily forgotten. So it is very important to practice understanding mathematical concepts in students. So that it has an impact on student errors in understanding mathematical concepts. Example: a student's error is that the student forgets (mistakenly) uses a formula to be used in solving a problem caused by the tendency of students to only memorize the formula, not understand how the formula occurs, so that what they learn is easily forgotten. So it is very important to practice understanding mathematical concepts in students. So that it has an impact on student errors in understanding mathematical concepts. Example: a student's error is that the student forgets (mistakenly) uses a formula to be used in solving a problem caused by the tendency of students to only memorize formulas, not to understand how the formula occurs, so that what they learn is easily forgotten. So it is very important to practice understanding mathematical concepts in students.

National Council of Teachers of Mathematicsstates that mathematics learning should be carried out in an effort to develop problem solving skills, reasoning, and proof, mathematical connections, mathematical communication, and representation (NCTM, 2000). Problem solving can be used as a technical approach and purpose of learning mathematics to find a solution to a mathematical problem. Polya in Hudojo (2003) explains problem solving as a solution or an effort to find a way out of difficulties, achieving a goal that cannot be achieved immediately, so it can be said that problem solving is the main activity in learning mathematics, problems can be presented in the form of story problems. or non-stories, depictions of phenomena or events, illustrated images or puzzles. According to Suherman (2003: 
In addition, Syafrianto's (2014) study found a low understanding of elementary students' mathematical concepts and teacher complaints in teaching, this can be seen when students still think mathematics is easy, but the longer the students feel that they do not like mathematics even more and are afraid because they feel difficult and not. understand how to complete tasks. Kesumawati (2008) states that the main principle in learning mathematics is to improve and prepare learning activities that are beneficial to students.

The findings in the field found that the results of the fifth grade students of Maria Fatima Bangkalan Christian Elementary School were still below the Minimum Completeness Criteria value $\leq 70$.This shows that students' ability to understand concepts and solve mathematical problems needs to be improved through interactive and easy learning. This kind of condition needs further study regarding the use of the learning approach. One way that can be done is to emphasize student development in forming questions or making questions (problem posing). Problem posing is one of the core mathematical activities so that it is a very important component in the mathematics curriculum as stated by English (1997: 83).

Problem posing learning activities, to guide students in formulating or asking problems or questions based on the situations given by the teacher. In the formulation of problems, students must think and reason, create and communicate mathematical ideas, cooperate and argue in formulating and solving problems, use available information to solve problems and think of the most appropriate and sensible way to solve problems that have been formulated. In addition, problem posing provides the widest possible opportunity for students to construct their thoughts in forming problems or making questions.

Field findings from the observation of learning at SDK Maria Fatima have been very good. Basically, the principles of learning in SDK are very good, namely: the principles of learning that are not only done in school, but learning can be done at home or in the community. However, there are some grade V SDK students who have less than optimal learning outcomes, namely in the flat shape material. Based on the results of daily tests of flat shape material, most SDK students have not completed the Minimum Completion Criteria. Of the 26 students, only 10 students scored above the Minimum Completeness Criteria.

The solution to increasing the value of the students' Minimum Completeness Criteria is through the use of media in learning which is used to explain the material to be conveyed in learning which is also used as a medium so that students better understand the material presented. In this study, the media used was the Hot Potatoes application. The Hot Potatoes application is a tool for creating a question bank. The Hot Potatoes Program consists of six programs that can be used to create interactive web-based teaching materials. This is in line with previous research conducted by Awalia and Rusma (2013) regarding "The use of Hot Potatoes media to improve student learning outcomes in the cognitive domain in information and communication technology subjects. The findings of this study were that there was an increase in student learning outcomes in the cognitive domain after using Hot Potatoes media in the subject. In connection with the use of computer technology in the field of mathematics education, NCTM (2000) states that electronic technology such as calculators and computers is essential to assist learning and mathematical activities.

The purpose of this research is (1) to analyze the effect of problem posing learning with the help of the Hot Potatoes application on understanding concepts in mathematics in fifth grade; (2)to analyze the effect of problem posing learning with the help of the Hot Potatoes application on problem solving in mathematics in fifth grade; and (3) uto analyze influence learning problem posing with the help of the Hot Potatoes application to understanding concepts and solving problems together in mathematics in fifth grade

\section{THEORETICAL FRAMEWORK}

\section{$>$ Understanding of Mathematic Concepts}

Hiebert and Carpenter (1992) argue that understanding is the most fundamental aspect of learning and any mathematics learning focuses more on embedding concepts based on understanding, because the meaning cannot be understood, only by memorizing it. Nuzilatus (2014: 11) defines understanding is a person's ability to grasp the meaning and meaning of the material being studied, which is stated by describing the main content of a reading or changing the data presented in a certain form to another.

Understanding the concept is a very important aspect of learning, because by understanding the concept students can develop their abilities in any subject matter. Concept understanding consists of two words, namely understanding and concept. According to Sardiman (2010: 43) understanding is a standard set of educational programs that reflects competence so that it can lead students to be competent in various sciences, while a concept according to Oemar Hamalik (2008: 162) is a class or category of stimuli that have characteristics general. So conceptual understanding is mastering something with a mind that contains a class or category of stimuli that have general characteristics.

The essence of learning mathematics is understanding concepts. If students are going to learn a new concept, then students must master the concept that underlies the concept. This is because the concepts in mathematics are arranged systematically, hierarchically, and logically from simple to complex. To master mathematical concepts, it is not enough to memorize formulas and strategies in solving problems. Many students waste their time just memorizing the formula and don't understand what it means. Even though conceptual understanding is important to achieve meaningful mathematics learning. The higher the students 'conceptual understanding of the material being studied, the 
higher the students' conceptual understanding of the material being studied, the higher the learning success rate (Retnowati, 2013)

Brownell in Suhenda (2007) suggests that one way for students to develop an understanding of mathematics is by using certain objects that they already know and are relevant to the concept being discussed. Under these conditions, the objects used can be manipulated by students so that they can understand the meaning of the mathematical concepts and skills they have just learned. Someone is said to understand something if he has been able to organize and restate what he has learned using his own sentences.

\section{> Math Problem Solving}

According to Ruseffendi (2006) states that a problem is a problem for students if the question is unknown or the student does not have a certain algorithm to solve it. A question is categorized as a problem or not depending on the student who faces the question. A problem for one student is not necessarily a problem for another student. A problem for students at a certain level of school is not necessarily a problem for a higher school level.

Nakin (in Mahmudi, 2008) argues that problem solving is a process that involves the use of certain steps (heuristics) which are often referred to as models or problem-solving steps, to find a solution to the problem. Heuristics are general steps as guides to solving a problem, although they do not necessarily guarantee successful problem solving. This is in line with Gagne's opinion (in Mahmudi, 2008) that defines problem solving as a process of synthesizing various concepts, rules, or formulas for solving problems. Polya (in Mahmudi, 2008) provides heuristics or general steps for problem solving, namely: (1) understanding the problem or problem; (2) create a solution plan; (3) carry out the solution plan; (4) recheck

Mathematical problem solving is seen as a process and goal of learning mathematics, a process as a technique and an approach whereas as a goal means a cognitive ability that is achieved after the learning process. According to Polya in Mahmudi (2008) "solving a problem is finding the unknown means to a distinctly conceived end" which means solving a problem is an attempt to find something that is not yet known in a suitable way. Meanwhile, according to Siswono (2008) problem solving is a process or individual effort to respond or overcome obstacles or constraints when an answer or method is not yet clear. Problem solving is a human activity that combines previously acquired concepts and rules, and is not a generic skill.

\section{$>$ Learning Problem Posing}

Problem posing is solving problems through elaboration, namely reformulating the problem into simpler parts so that they are understood. The syntax is understanding, solutions, identification of mistakes, minimizing writing count, looking for alternatives, compiling questions (Suyatno, 2009). Problem Posing is a term in English which consists of the words "problem" and "pose". Posing has the equivalent meaning "question formation" or "question submission".

According to Brown and Walter stated that in 1989, for the first time the term problem posing was officially recognized by the National Council of Teachers of Mathematics (NCTM) as part of the National Program for Re-Direction of Mathematics Education (reform of mathematics education). Problem Posing is an important component of mathematics (Brown and Walter: 1993. NCTM: 2000). In principle, according to Suyitno Amin, problem posing is a learning model that requires students to ask their own questions through learning questions (practicing questions) independently. This means that students must master the material and the sequence of solving questions in detail and this will be achieved if the knowledge is not only from the teacher but needs to learn independently. The problem posing learning model was developed in 1997 by Lyn D. English and was initially applied in mathematics. Furthermore, this model was also developed in other disciplines (Amir Mahmud and Bestari Dwi, 2008).

This problem posing approach is supported by constructivism theory, which is a learning theory which says that knowledge is not simply transferred from the teacher's mind to the student's mind. This means that students mentally build their knowledge structure based on their cognitive maturity. In this connection, Cobb (1992) describes that "learning is seen as an active and constructive process in which students try to solve problems that arise as they actively participate in mathematics exercises in the classroom. This is in accordance with the problem posing approach where students are required to make new questions in their own words. Students actively do thinking activities to make questions.

The steps for applying the problem posing model proposed by Amri and Saminanto are in line with the opinion of Thobroni and Mustofa (2012) which states that 1) the teacher explains the subject matter to students using props to facilitate students in asking questions, 2) students are asked to ask questions in groups, 3) students exchange the questions that have been asked, 4) then answer the questions with the group.

\section{The Hot Potatoes Application}

Hot potatoes is a web-based interactive teaching and question material, which can produce several types of output files, you can format the output in the form of Web pages (.htm), compressed files (.Zip), SCORM 1.2 package files (.Zip) or You can also print directly to a printer or send to a server (upload) on an LMS that supports standard e-learning application content with SCORM, for example the Dokeos LMS. 
ISSN No:-2456-2165

The steps in learning problem posing assisted by hot potatoes are described in the explanation below.

- Initial activities, things that are done at this stage are students are given story questions without questions, but all the information needed to solve the problem is there. The student's task is to make questions based on this information.

- The main activities, the things that are done at this stage are (1) The teacher selects a topic and asks students to divide into groups. Each group is assigned to make a story problem as well as its solution. Then the questions were solved by other groups. Previously, the questions were given to the teacher for editing about their kindness and readiness. These questions will be used as an exercise later. The name of the question maker is shown but the solution is not. These questions are discussed in each group and class. This will provide value for communication and learning experiences. The discussion is around whether the question is ambiguous or not. The questions made by students depend on the interests of each student. As an extension, students can ask story questions that are made individually. (2) Students are given questions and asked to list a number of questions related to the problem. A number of questions are then selected from the list to be completed. Questions can depend on other questions. It can even be the same, but the words are different. By listing questions related to the problem will help students "understand the problem", as one aspect of problem solving by Po

- The final activity, what is done at this stage is the students do the evaluation and discuss together about the results of the evaluation.

\section{RESEARCH METHOD}

This research uses an experimental quantitative approach.Experimental research according to Creswel (2008: 299) is used when the researcher wants to establish possible causes and effects between the independent and dependent variables. This study will show that learning problem posing using the hot potatoes application as the independent variable $(\mathrm{X})$ on the ability of understanding concepts and problem solving respectively as the dependent variable (Y1 and Y2) for elementary school students. In this study using a quasi-experimental design nonequivalent control group design. In this design, the experimental group and the control group were not chosen randomly, but used groups that were already available at school.

\begin{tabular}{|c|c|c|c|}
\hline Class & Pretest & Treatment & Posttest \\
\hline Experiment & $\mathrm{O} 1$ & $\mathrm{X}$ & $\mathrm{O} 2$ \\
\hline Control & $\mathrm{O} 3$ & $\mathrm{C}$ & $\mathrm{O} 4$ \\
\hline
\end{tabular}

Table 1:- Nonequivalent Control Group Design

Information:

O1 : Initial test in the experiment group

$\mathrm{O} 2$ : The final test in the experiment group

$\mathrm{X}$ : Learning problem posing using hot potatoes application

C : Direct learning model

O3 : Initial test in the control group

O4 : The final test in the control group

The research subjects were fifth grade students of Maria Fatima Christian Elementary School and Marga Bhakti Sukun Malan Christian Elementary School. The sample in this study amounted to 26 students.Collecting data in the study using a test description. The description test used was given twice, namely pretest and posttest, for the pretest was given before treatment. Meanwhile, the posttest was given using the problem posing learning model. From this test, the value of the students' concept understanding and problem solving abilities before and after the treatment was given.

Prior to data analysis, the researcher conducted a validity test and a reliability test which aimed to determine the feasibility of an instrument. The data collected from the results of the distribution of the instruments were then analyzed using the normality test and the homogeneity test. After that, the hypothesis is tested.

\section{RESULTS}

Before being used for research, the instruments used were validated first by an expert validator. The validation results by the validator are presented below.

The data description was carried out to describe the students' conceptual understanding data obtained in the study. The concept understanding data was obtained after assessing the experimental class with and the control class on concept understanding, in the form of multiple choice questions consisting of 10 questions. The 10 question test was used to measure the understanding of Mathematical concepts after participating in the treatment, namely learning using the Problem Posing learning model based on the Hot Potatoes application.

The students' conceptual understanding data in the control and experimental classes were tested by means of 10 questions pre-test and post-test. The scores for understanding the concept of mathematics are as follows. 
ISSN No:-2456-2165

\begin{tabular}{|c|c|c|c|}
\hline \multirow{2}{*}{ Group } & \multirow{2}{*}{ Treatment } & Mean Value & \multirow[b]{2}{*}{ Category } \\
\hline & & Concept understanding & \\
\hline \multirow{2}{*}{ Direct Method } & Pre Test & 61,042 & Not complete \\
\hline & Post Test & 73,958 & Not complete \\
\hline \multirow{2}{*}{$\begin{array}{l}\text { Problem Posing learning based on the Hot } \\
\text { Potatoes application }\end{array}$} & Pre Test & 58,958 & Not complete \\
\hline & Post Test & 85,833 & Completed \\
\hline
\end{tabular}

Table 2:- Understanding of Mathematical concepts in terms of the Learning Model Source: Data processed by the author, 2020

The results of the Mathematics learning score by applying the learning model in table 2, it can be seen that the Problem Posing method based on the Hot Potatoes application is better than the Direct Learning Model, with an average post-test result score of 85,833 , meaning that the students in that group are included in the complete category.

Students' conceptual understanding data in the control and experimental classes through measuring the problem-solving ability with 10 instruments. The scores of students' understanding of mathematical concepts in the high and low problem-solving ability group are shown in table 3 .

\begin{tabular}{|c|c|c|}
\hline \multirow{2}{*}{ Treatment } & Problem solving skill & $\begin{array}{c}\text { Score of Mathematical Concept } \\
\text { Understanding }\end{array}$ \\
\hline \multirow{3}{*}{ Pre Test } & Low & 53,636 \\
\cline { 2 - 3 } & High & 61,892 \\
\cline { 2 - 3 } & Total & $\mathbf{6 0 , 0 0 0}$ \\
\hline \multirow{3}{*}{ Post Test } & Low & 74,545 \\
\cline { 2 - 3 } & High & 81,486 \\
\cline { 2 - 3 } & Total & $\mathbf{7 9 , 8 9 6}$ \\
\hline
\end{tabular}

Table 3:- Understanding of Mathematical concepts in terms of problem-solving ability levels Source: Data processed by the author, 2020

The table above shows that the majority value of the mean score of understanding the concept of post test with high problem solving ability of 81,486 lies in the complete learning category, while understanding the concept of pre test with low problem solving ability is 53,636 .

Students' conceptual understanding data in the control and experimental classes through the interaction between learning models and problem-solving abilities. The scores for students' understanding of mathematical concepts in the high and low problem-solving ability group are shown in table 4 below.

\begin{tabular}{|c|c|c|}
\hline \multirow{2}{*}{ The Chase Model } & Problem solving skill & $\begin{array}{c}\text { Score of Mathematical Concept } \\
\text { Understanding }\end{array}$ \\
\hline \multirow{2}{*}{$\begin{array}{c}\text { Learning methods } \\
\text { Live }\end{array}$} & Low & 74,167 \\
\cline { 2 - 3 } & High & 73,889 \\
\cline { 2 - 3 } & Total & $\mathbf{7 3 , 9 5 8}$ \\
\hline \multirow{2}{*}{$\begin{array}{c}\text { Problem Posing learning based on } \\
\text { the Hot Potatoes application }\end{array}$} & Low & 75,000 \\
\cline { 2 - 3 } & High & 88,684 \\
\hline
\end{tabular}

Table 4:- Understanding the concept after interaction

Source: Results of SPSS Data Processing

Table 4 shows a description of students' conceptual understanding of the interaction of the learning model with high problem solving abilities, showing the average value of understanding the concept of the Problem Posing learning model based on the Hot Potatoes application of 88,684 better than the Direct learning model of 73,889 .

The normality test in this study used one sample Kolmogorov-Smirnov. To find out whether the data is normal or not, it can be seen from the $p$-value calculated for each variable to be studied. The test criteria are if the asymp.sig ( 2 tailed) value is $\geq 0.05$, then the data is normally distributed. Conversely, if the asymp.sig ( 2 tailed) value $\leq 0.05$ then the data is not normally distributed. 
ISSN No:-2456-2165

\begin{tabular}{|c|c|c|c|}
\hline Group & Variable & $\begin{array}{c}\text { Kolmogorov } \\
\text { Smirmov }\end{array}$ & Significance \\
\hline \multirow{3}{*}{$\begin{array}{c}\text { Control } \\
\text { (Direct learning model) }\end{array}$} & Understanding the concept of Pre Test & 0.839 & 0.483 \\
\cline { 2 - 4 } & $\begin{array}{c}\text { Understanding the concept of the Post } \\
\text { Test }\end{array}$ & 1,271 & 0.079 \\
\cline { 2 - 4 } $\begin{array}{c}\text { Experiment } \\
\text { (Learning model }\end{array}$ & Results Problem solving ability & 1,292 & 0.077 \\
\hline \multirow{2}{*}{$\begin{array}{c}\text { Problem Posing based on the Hot Potatoes } \\
\text { application) }\end{array}$} & Understanding the concept of Pre Test & 1,059 & 0.212 \\
\cline { 2 - 4 } & $\begin{array}{c}\text { Understanding the concept of the Post } \\
\text { Test }\end{array}$ & 0.573 & 0.898 \\
\cline { 2 - 4 } & Results Problem solving ability & 1,114 & 0.237 \\
\hline
\end{tabular}

Table 5:- Normality Test Results

Source: Data processed by the author, 2020

Based on table 5 above, the results of the Normality Test can be seen that the value of the significance level or the probability value of the Kolmogrorov-Sminov test of normalty is 0.483 for the pretest of direct understanding of the concept. Meanwhile, the posttest in the Lansung group was 0.079 . The result of the problem-solving ability test, the significance level value is 0.079 . The three test results are more than 0.05 , so it can be concluded that the data distribution of the pretest, posttest and problem solving abilities of the direct group is following the normal distribution.

In the Problem Posing group based on the Hot Potatoes application, the significance level value for understanding the pretest concept was 0.212. Meanwhile, the posttest was 0.898 . The result of the problem-solving ability test, the significance level is 0.237 . The three test results are more than 0.05 , so it can be concluded that the data distribution of the pretest, posttest and problemsolving ability of the Problem Posing group based on the Hot Potatoes application is following the normal distribution.

According to Ghozali (2014) that homogeneity can be done using the Levene's Test, by looking at the significance level of the calculated Levene $\mathrm{F}$ value. If the calculated Levene $\mathrm{F}$ value shows a significance level of more than 0.05 , it can be said that there is no difference in variance between sample groups or in other words the variance between groups is the same. The results of the homogeneity test can be seen in Table 6 below:

\begin{tabular}{|c|c|c|c|}
\hline \multicolumn{5}{|c|}{$\begin{array}{c}\text { Levene's Test } \\
\text { Dependent Variable: Post Understanding the concept }\end{array}$} \\
\hline F & df1 & df1 & Sig. \\
\hline 0.111 & 3 & 44 & 0.953 \\
\hline
\end{tabular}

Table 6:- Homogeneity Test (Levene's test) Posttest

Source: Data processed by the author, 2020.

Based on table 6 of the homogeneity test, it can be seen that the Levene $F$ value of the variable understanding of Mathematical concepts and the results of the problem solving ability in the Lansung group and the Problem Posing group based on the Hot Potatoes application shows a significance level of 0.953 which means greater than 0.05 , so the null hypothesis which states " there is no difference in variance between sample groups "is accepted or in other words the variance between groups of variables of understanding mathematical concepts and test results of problem solving ability is the same or homogeneous.

After testing the requirements analysis, the next step is to analyze the data. The data analysis technique used in this study was the two-way covariance analysis test, because the conceptual understanding variable fulfills the normality assumption, a twoway covariance analysis test is used. 
The following are the results of hypothesis testing using two-way covariance analysis techniques as follows.

\begin{tabular}{|c|c|c|c|c|c|}
\hline \multicolumn{7}{|c|}{ Test of Between - Subject Effect } \\
\hline \multicolumn{7}{|c|}{ Dependent Variable: Post Test Understanding the concept } \\
\hline Source & $\begin{array}{c}\text { Type III Sum Of } \\
\text { Square }\end{array}$ & df & Mean Square & F & Sig \\
\hline Corrected Model & $2433.763 \mathrm{a}$ & 3 & 811,254 & 9,672 & .000 \\
\hline Intercept & 204656,005 & 1 & 204656,005 & 2439,869 & .000 \\
\hline Group & 514,379 & 1 & 514,379 & 6,132 & .017 \\
\hline Problem solving skill & 378,501 & 1 & 378,501 & 4,512 & .039 \\
\hline $\begin{array}{c}\text { Group * Problem solving } \\
\text { ability }\end{array}$ & 410,520 & 1 & 410,520 & 4,894 & .032 \\
\hline Error & 3690,716 & 44 & 83,880 & & \\
\hline Total & 312525,000 & 48 & & & \\
\hline Corrected Total & 6124,479 & 47 & & & \\
\hline \multicolumn{7}{|c|}{ R Squared $=0.397$ (Adjusted R Squared = 0.246) } \\
\hline
\end{tabular}

Table 7:- Results of Two Path Covariance Analysis

Source: Data processed by the author, 2020

Based on table 7, the 2 Path Anova test results, are used to answer the hypothesis of this study, as follows.

First hypothesis. Based on the SPSS output, it is obtained a significance probability value $<0.05$, the conclusion is that $\mathrm{HO}$ is rejected and $\mathrm{H} 1$ is accepted. It is proven that there is a significant influence between Problem Posing learning based on the Hot Potatoes application on the understanding of the concept of mathematical problems of students in grade V SDK Maria Fatima Bangkalan. The results of the calculation show that the post-test mean score of understanding Mathematics concepts in the Lansung group is 73,958 (minimum completeness criteria), while the average value of concept understanding in the Problem Posing group based on the Hot Potatoes application is 85,833 (the minimum completeness criterion is complete). From this average value, relatively it can be said that there is a difference in understanding the concept of Mathematics between the control group (Lansung) and the experiment (Problem Posing based on the Hot Potatoes application), strengthened by the results of the F test, namely the Fcount of the Group $=6.132$ with a significant level ( $\mathrm{sig}$ ) of 0.017 , meaning less than 0.05 . This proves that there is a significant difference in understanding Mathematical concepts between the control and experimental groups, in other words the application of the Problem Posing model based on the Hot Potatoes application is better than the Direct learning model in increasing concept understanding. Math in students five Maria Fatima Christian Primary Schools in Bangkalan.

Second Hypothesis. Based on the SPSS output, it is obtained a significance probability value $<0.05$, the conclusion is that $\mathrm{HO}$ is rejected and $\mathrm{H} 1$ is accepted. This is proven by the research hypothesis which reads: "There is a significant influence between Problem Posing learning based on the Hot Potatoes application on solving math problems of students in fifth grade of Maria Fatima Bangkalan Christian Elementary School". The results of the F test, namely the value of Fcount of problem-solving ability $=4.512$ with a significant level ( $\mathrm{sig}$ ) of 0.039, meaning less than 0.05 . This proves that there is a significant influence between Problem Posing learning based on the Hot Potatoes application on solving math problems of students in the fifth grade of Maria Fatima Bangkalan Christian Elementary School.

Third hypothesis. Based on the SPSS output, the results of testing the effect of the variables between the problem posing learning group using the hot potatoes application and the problem-solving ability of understanding mathematical concepts show that the $F$ value of the interaction is 4.894 or with a significant level of 0.032 . The significance probability value $<0.05$, the conclusion is that $\mathrm{H} 0$ is rejected and $\mathrm{H} 1$ is accepted. The significant level obtained from the test results is less than 0.05 , this proves that there is an interaction between the Problem Posing learning model based on the Hot Potatoes application with the direct learning model and the problemsolving ability to understand Mathematical concepts in fifth grade students of Maria Fatima Bangkalan Christian Elementary School, so that the hypothesis all three are acceptable.

\section{DISCUSSION}

$>$ The Effect of Learning Problem Posing Based on the Hot Potatoes Application on Students' Understanding of Mathematical Problem Concepts in the fifth grade of Christian Elementary School Maria Fatima Bangkalan

The problem-based learning model is more effectively used in learning, this is in accordance with Nur (2011:33) who states that the problem-based learning model demands student activity when compared to using conventional learning models. The benefit of raising a problem at the beginning of learning can trigger student thinking so that students will try to solve it scientifically. Margetson (in Rusman, 2012:230) explains that problem-based learning improves the development of students' thinking skills. Problem-based learning facilitates students to solve problems and interpersonal skills better than other learning models. In addition, it creates interactions between students 
and teachers and fosters the courage of students to speak up to express their opinions.

Based on the results of the observations it is evident that there is a significant influence between Problem Posing learning based on the Hot Potatoes application on the understanding of the concept of mathematical problems of students in the fifth grade of the Maria Fatima Bangkalan Christian Elementary School. The proof of this hypothesis is reinforced by the difference in the mean value of understanding mathematical concepts in the experimental group (Problem Posing model based on the Hot Potatoes application) which is higher by 85,833 (Very Good), than the average value of understanding mathematical concepts in the control group (direct learning model). ) of 73,958 (Good).

The results of this study are in line with the opinion of learning with the problem posing approach showing student learning activities are more active in determining how to understand conceptual understanding and explain to others about what they are learning. The advantages of the problem posing approach according to Silver, Brown, and Walter are (1) it is useful for the development of knowledge and understanding of mathematical concepts; (2) encouraging students to be responsible in their learning; (3) increase student curiosity.

This is in line with what Slavin stated, which states that the learning and learning process of students must be actively involved and students become the center of learning and learning activities in the classroom. Teachers can facilitate this process by teaching in ways that make information meaningful and relevant to students. For this reason, teachers must provide opportunities for students to find and apply their own ideas, in addition to teaching students to be aware and aware of their own learning strategies.

The results of Arrahim and Fatimah's study (2018) also reinforce this study which found that there was an increase in students' understanding of concepts after the Problem Posing model. It can be concluded that the use of the Posing model can improve students' understanding of concepts in Indonesian mathematics students of class $\mathrm{V}$ SDI-Huda AL Bekasi Timur. From the results obtained, the average value of the ability to understand the concept of students in the first cycle was 75.28 with a success percentage of $60.87 \%$. Then in the second cycle, the average value of students' understanding of the concept of the ability to increase with success rates of 90.11 and $86.96 \%$.

Likewise, the results of Wulandari's (2015) study found that through the problem-posing approach the understanding of mathematics concepts in grade IV elementary school students increased, by using a direct learning model, the understanding of mathematics concepts in grade IV elementary school students increased, an increase in the ability to understand mathematical concepts of students who received learning using the problem approach posing is better than students who get learning using direct learning models.

> The Effect of Learning Problem Posing Based on the Hot Potatoes Application on Mathematical Problem Solving Students in fifth grade Christian Primary School Maria Fatima Bangkalan

Trianto (2010: 94) suggests that the goal of problembased learning is to help students develop thinking skills and problem-solving skills, then learn the role of authentic adults. Problem-based learning has implications: a) encouraging cooperation, b) encouraging observation and dialogue with others, and c) involving students in investigating their own choices so that students can explain real-world phenomena independently, become independent learners in solving problems with directions teacher. The same thing was echoed by Ibrahim and Nur (2000: 19) regarding Vigotsky's learning theory that believes that social interaction with friends spurs the formation of new ideas and enriches students' intellectual development.

The results of the observation proved that there was a significant influence between Problem Posing learning based on the Hot Potatoes application on solving math problems of students in fifth grade Christian elementary school Maria Fatima Bangkalan. The proof of this hypothesis is supported by the difference in the average value of the assessment of mathematical conceptual understanding based on high problem solving skills in the experimental group of 88,684 (Very Good), while the average assessment of understanding mathematical concepts based on high problem solving skills in the control group is 73,889 (Good ). This shows that students who have problem solving skills by applying problem-based learning models have an impact on increasing understanding of mathematical concepts.

The results of this study are in line with the opinion of Widodo and Kartikasari (2017) who found differences in students' mathematical problem solving abilities between classes using the Creative Problem Solving learning model and those using conventional methods. It takes an understanding of mathematical concepts to be able to solve problem solving skills.

The results of this study are also strengthened by a study conducted by Saptono, Wahyudi, and Indarini (2019) which found that the increase in problem solving ability at the pretest stage obtained a completeness percentage of $40.95 \%$, cycle I of $72.7 \%$, and increased in cycle II to $90.9 \%$. So it can be concluded that the application of the problem posing method can improve students' problem solving abilities.

Likewise, a study conducted by Saptono, Wahyudi, and Indarini (2019) found that an increase in problem solving ability at the pretest stage obtained a completeness percentage of $40.95 \%$, cycle I of $72.7 \%$, and increased in cycle II to $90,9 \%$. So it can be concluded that the application of the problem posing method can improve students' problem solving abilities. 
$>$ The Effect of Learning Problem Posing based on the Hot Potatoes application on the Understanding of Mathematical Concepts and Problem Solving Students in fifth grade Christian Elementary School Maria Fatima Bangkalan

The results of the observations proved that there was a significant influence between Problem Posing learning based on the Hot Potatoes application on understanding the concept and solving math problems of students in fifth grade Christian Elementary School Maria Fatima Bangkalan.

The results of this study are one of the active learning approaches that are conducive to the creation of an active learning atmosphere in order to form understanding of concepts and solving students' mathematical problems is to use the Problem Posing learning approach, namely learning to optimize the use of all the potential of students, so that all students students can achieve satisfactory learning outcomes in accordance with their personal characteristics. A concept in mathematics is the main understanding that underlies the subsequent meanings. Basically, the concept is a stimulus class which has general characteristics. A concept is a class or category of stimulus which has general characteristics. A stimulus is an object or person (person).

\section{CONCLUSIONS AND SUGGESTIONS}

\section{A. Conclusion}

Based on the research that has been carried out and the results of the analysis, it is concluded that (1) there is an effect of problem posing learning with the help of the Hot Potatoes application on understanding concepts in mathematics in fifth grade; (2) There is an effect of problem posing learning with the help of the Hot Potatoes application on problem solving in mathematics in fifth grade; (3) The hot potatoes application based problem posing learning can jointly influence the conceptual understanding and problem solving in mathematics in fifth grade.

\section{B. Suggestion}

It is hoped that teachers will be more proactive in developing and improving students' understanding of mathematical concepts and problem solving through the introduction of problem posing learning based on the hot potatoes application. G.uru can further improve students' knowledge and development of conceptual understanding and mathematical problem solving through the introduction of the hot potatoes application. And this study becomes a learning science reference for teachers to arrange questions easily, practically and attractively for students, so that students are not bored and bored with the hot potatoes application-based problem posing learning process.

It is hoped that researchers can become a means to practice the learning process in mathematics through research activities to gain direct experience in making evaluation questions using the Hot Potatoes application and directly examine the learning process in class using these applications and increase the writer's insight to think critically and systematically in facing students' difficulty understanding concepts and solving math problems. This research can contribute to the development of conceptual understanding and mathematical problem solving, especially in mathematics and can be used as a reference for further research.

\section{REFERENCES}

[1]. Ahmadi, Abu. (2015). General Psychology. Jakarta: PT. Rineka Copyright.

[2]. Abu-Elwan, R. (2000). Effectiveness of Problem Posing Strategies on Perspective Mathematics Teachers' Problem Solving Performance.

[3]. Amri, Sofan. (2013). Development and Learning Models in the 2013 Curriculum. Jakarta: Prestasi Pustaka Raya.

[4]. Arikunto, S. (2006). Research Procedures (A Practice Approach). Jakarta: Rineka Cipta

[5]. Anggoro, Toha. (2009). Research methods. Jakarta: Open University

[6]. BSNP. (2006). Content Standards for Primary and Secondary Education Units. Jakarta: National Education Standards Agency

[7]. Brown, S. \& Walter, R. (2005). The Art of Problem Posing. New Jersey: Lawrence Erlbaum Associates Publishers.

[8]. Cobb, P., Wood, T., Yackel, E., \& McNeal, B. (1992). Characteristics of classroom mathematics traditions: An interactional analysis. American Educational Research Journal, 29 (3), 573-604.

[9]. Creswell, JW (2012). Research design: qualitative, quantitative, and mixed approaches. Yogjakarta: PT Pustaka Pelajar.

[10]. Darmawan. (2013). Quantitative Research Methods. Bandung: Youth Rosdakarya.

[11]. Ministry of National Education. (2006). Education Unit Level Curriculum. Jakarta: Depdiknas

[12]. Ministry of National Education. (2010). Playgroup Implementation Technical Guidelines. Jakarta: Directorate of Early Childhood Education, Directorate General of PNFI.

[13]. English, Lyn D. (1997). Promoting a Problem-Posing Classroom. Teaching Children Mathematics, November 1997, 172-179.

[14]. Hamalik, Oemar. (2008). Teaching Planning Based on a Systems Approach. Jakarta: Earth Literacy.

[15]. Hiebert, J. \& Carpenter PT (1992). Learning and Teaching with Understanding. In DA Grouws (Ed.) Handbook of Research on Mathematics Teaching and Learning. New York: Macmillan Publishing Company.

[16]. Hosnan, M. (2014). Scientific and Contextual Approaches in 21st Century Learning. Bogor: Ghalia Indonesia.

[17]. Hudojo, Herman. (2003). Curriculum Development and Mathematics Learning. Malang: Neegeri University Malang.

[18]. Krulik, Stephen \& JA Rudnick, (1988). Problem Solvig: A Handbook for Elementary School Theacers. Boston: Allyn \& Bacon Inc. 
[19]. Mahmud, A., \& Handayani, BD (2009). The Effectiveness of the Application of Problem Posing Methods and Structured Assignments on Learning Achievement in Accounting Subjects Subject Adjustment of Journal Semester I Students of Accounting Department. Journal and Proceedings of SNA - National Symposium on Accounting, 11

[20]. Mahmudi, Ali. (2008). Learning Problem Posing to Improve Mathematical Problem Solving Ability. Paper Presented at the National Mathematics Seminar Organized by the Mathematics Department FMIPA UNPAD Collaborating with the UI Mathematics Department Saturday, December 13, 2008.

[21]. Mutohar, Ali. (2016). Analysis of the ability to understand mathematical concepts of grade IX students of SMP Negeri 1 Pandanarum on the material of congruence and congruence. Essay. Purwokerto: Muhammadiyah University of Purwokerto.

[22]. Nasution, MN (2005). Integrated Quality Management: Total Quality Management. Bogor: Second Edition, Ghalia Indonesia.

[23]. NCTM. (2000). Principles and Standard for School Mathematics. Resto, Virginia: The National Council of Teachers of Mathematics, Inc.

[24]. Nuzilatus, Retno S. (2014). Improved Understanding of Globalization Material Pkn Subjects with Critical Incident Strategies in Class IV Mi Ma'arif $\mathrm{Nu}$ Sukodadi Students. Thesis, Surabaya: UIN Sunan Ampel Surabaya

[25]. Permendikbud. (2016). Regulation of the Minister of Education and Culture Number 24 of 2016 concerning Core Competencies and Basic Competencies of Subjects in the 2013 Curriculum in Primary and Secondary Education.

[26]. Polya, G. (1973). How to Solve it. New Jersey: Princeton University Press.

[27]. Retnowati, D., \& Murtiyasa, B. (2013). Efforts to Improve Understanding of Mathematical Concepts and Dispositions Using the Treffinger Learning Model. National Seminar on Mathematics Education, 14-23

[28]. Ruseffendi, ET (2006). Introduction to Helping Teachers Develop Competence in Teaching Mathematics to Improve CBSA. Bandung: Tarsito

[29]. Rusman. (2014). Learning Models (Developing Teacher Professionalism). Jakarta: Raja Grafindo Persada.

[30]. Sardiman, AM (2010). Teaching and Learning Interaction and Motivation. Jakarta: PT. Raja Grafindo.

[31]. Siswono, TYE (2008). Mathematics learning model based on submission and problem solving to improve creative thinking skills. Surabaya: Unesa University Press.

[32]. Siswono, TYE (2008). Problem Posing: A Democratic Learning Alternative. Surabaya: Unesa University Press.

[33]. Soedjadi. (2000). Mathematics Education Tips in Indonesia: Constant Present Conditions Towards Future Hope. Jakarta: Director General of Higher Education, Ministry of National Education.
[34]. Sugiyono. (2012). Qualitative and Quantitative Research Methods R \& D. Bandung: Alfabeta.

[35]. Sugiyono. (2012). Combined Research Methods (Mixed Methods). Bandung: Alfabeta.

[36]. Suhenda. (2007). Curriculum Development and Mathematics Learning. Jakarta Open University.

[37]. Suherman, Erman. (2003). Contemporary Mathematics Learning Strategies. Bandung: Indonesian Education University

[38]. Sukardi. (2003). Educational Research Methodology. Jakarta: Earth Literacy.

[39]. Sutejo, Agus. (2002). Learning Outcomes of Students Given the Task of Submitting Mathematics Questions Based on Two Different Information Presentations. Postgraduate Thesis. Surabaya: Surabaya State University

[40]. Suyatno. (2009). Exploring Innovative Learning. Sidoarjo: Masmedia Buana Pustaka.

[41]. Syafrianto. (2014). Improved mathematical understanding and reasoning abilities and habits of mind of junior high school students through the make a match type of cooperative learning model. Thesis. Bandung: Indonesian Education University.

[42]. Thobroni, Muhammad \& Mustofa, Arif. (2013). Learning and Learning Discourse Development and Learning Practices in National Development. Yogyakarta: AR ruzz Media.

[43]. Trianto (2008). Designing Contextual Teaching and Learning in the Classroom. Jakarta: Smart publisher libraries.

[44]. Upu, Hamzah. (2003). Problem Posing and Problem Solving in Mathematics Learning. Bandung: Ramadan Libraries.

[45]. Winarsunu, Sincere. (2006). Statistics in Psychological Research and Education. Malang: University of Muhammadiyah Malang. 